\title{
Genre form of the guide as an element of network travel text
}

\author{
E. Kryvka ${ }^{1}$, O. Mitchuk ${ }^{2}$ \\ ${ }^{1}$ Department of Social Communications, Academician Stepan Demianchuk International University of Economics and Humanities, \\ Rivne, Ukraine, \\ ${ }^{2}$ Institute of Journalism, Borys Grinchenko University of Kyiv, Kyiv, Ukraine ORCID ID: https://orcid.org/ 0000-0002-1011-7320 \\ Corresponding author. e-mail: gorvat.elya.1995@gmail.com
}

Paper received 06.12.21; Accepted for publication 19.12.21.

https://doi.org/10.31174/SEND-HS2021-261IX48-15

\begin{abstract}
Cultural communication, which is an effective connecting element in society is researched. It is found out that the processes of socialization and individual cultural interactions require further study and this, firstly, promotes a comfortable environment for interaction and expansion of cultures, and secondly, mutual understanding and mutual recognition of them in the modern world. It is considered that the main mechanism of the existence and development of society is cultural communication. Exactly it controls the possibility of forming cultural ties, managing common people's livelihoods, accumulation and transfer of experience. Culture, as well as communication, can be defined as a combination of natural and artificial signs (languages, symbols, images), through which the conservation, accumulation and transfer from generation to generation of accumulation personnel is transformed into new ideas, discoveries, deeds, which form the social memory and affect the future organization of cultures.
\end{abstract}

Keywords: guidebook, travelogue, cultural communication, art journalism, network.

Introduction. One of the important means of transmitting social and cultural information, and an element of the communication process, is travel journalism. It provides images of geographical space, the author's worldviews and judgments, understanding of different pictures of the world, provides cognitive-informative communication dialogue between the author and the recipients. Throughout its existence, the travelogue has changed, depending on historical, social and cultural conditions. Some genre features have changed, the usual palette of artistic means has been replenished and changed, but the greatest external historical and cultural environment has influenced the ideological and thematic orientation and communicative purpose of the genre. At the same time, the very essence of the travelogue, its basis is a guide, a description of the trip, a story about travel, that remained unchanged.

Modern travel media text condenses the features of a guide and travelogue, thus presenting a new form of travel journalism - travelogue. O. Alexandrov defined the threefold structure of this genre: man, way, world [2]. Therefore, understanding them as objects of mass communication cognitive interest is quite relevant in the modern media space. Travelogue, as a conservative genre form, is able to accumulate different types and genres of mass communication. Thus, it is necessary to study the genre-communication features of modern travel media texts, which are the linguistic personality of the publicist, his worldview, intellectual level and cognitive ability.

The theoretical basis of the study were the works of foreign and Ukrainian researchers such as: O. Alexandrov, M. Balina, M. Vaskiv, V. Huminskyi, O. Husieva, V. Zdoroveha, O. Ivanova, T. Kovaleva, E. Ponomarev, V. Rizun, M. Stufliaieva, S. Chorna, S. Chornous, O. Yakuba and others.

The purpose of the article is to analyze the structure and genre-communication features of the guidebook by $\mathrm{C}$. Augias "The Secrets of London" in the context of relevant genres and types of mass communication. This goal involves solving the following tasks: explore the expression of the worldview of the traveler-narrator, represented in the ways of understanding the facts; analyze the manifestation of genre features in the book; find out the specifics of journalistic understanding of reality in the book "The Secrets of London." The object of research is the guidebook by C. Augias "The Secrets of London." The subject is the genrecommunication features of the guidebook by C. Augias "The Secrets of London."

Materials and methods. The methodology and research methods are determined by the specifics of the object, subject, purpose and objectives of the master's thesis. The methodology is based on a systematic approach as a modern philosophical school. Adherence to it gives a possibility to better understand the features of the genre of travelogue as a mass communication phenomenon. The methods that were used to achieve the goal of research and problem at different stages of the work: classification, analysis and synthesis; historical and biographical, typological and logical approaches. This allowed us to cover a complex and diverse subject of study.

The guidebook as a separate genre exists somewhat conditionally. It is first of all a special form, which is distinguished by the presence of certain background information that helps to plan and make trips, navigate in a certain place during the journey. Thus, the functions of the guidebook is to inform the recipient about the topographic and sociocultural space of a particular city or region; provide accurate and accessible historical facts; emphasize the natural, economic or social features of the described area.

Results and discussion. Guidebooks first appeared in writing in ancient Greece and were called "periodos ges," they existed until the IV century AD. Over time, there were trips for a specific purpose, which were related to trade, diplomatic and scientific activities, military affairs and religion. A. Bidun notes, that nowadays the role of aestheticization of the guidebook is growing, attempts are being made to bring it closer to the art publication [3].

Any documentary text about the journey functions primarily as the content of mass intercultural communication, the main function of which is cognitive, knowing someone else through your own, and vice versa, knowing yourself as a representative of ethnic culture through understanding another.

O. Alexandrov points out that the verbal nature of travel, which is rooted in a specific sketch, opens up great oppor- 
tunities for human knowledge of the world, and the movement of the traveler along the route should be considered as a dynamic system of information situations [2, p. 13].

The researcher of traveling genres, applying the genetic method of travelogue research, stated that the structural basis of this genre is a guidebook. Accordingly, he noted that the special place and functions of the route of the traveler in the travelogue are explained by the specifics of the genre [2, p. 15].

N. Maslova writes that the route, consistent and clearly drawn by the author, characterizes the travelogue as a series of objective facts and events that the traveler encounters independently of his own will. Subjective selection of these facts is a manifestation of the author's intention, as the route of the trip in one way or another is ultimately determined by the will of the traveler [10, p. 72].

The book "The Secrets of London" by C. Augias has formal markers of the guidebook, and the main communication purpose of the author of which is to convey the necessary information to the recipient about the route of travel through the city, road features (mode of transport, ticket price, trip duration, living conditions in different areas), cultural monuments, short and deep historical excursions, biographical data, memories of eyewitnesses, reliability and accuracy of representation of separate representatives of the London community, archival documents, etc.

As a guide, the book "The Secrets of London" by C. Augias focuses on a special category of tourists - "deeply psychological people," those who are preparing not just for a trip, but for a deep knowledge of the character and behavior of a true Briton. Taking into account the depth of the author's penetration into the psychological essence of a typical Londoner, immersion in the historical past not only of the city but also of the monarchical country, it can be assumed that almost one hundred percent of readers are attentive tourists-researchers who do not ignore any details. The text of the guidebook "The Secrets of London" by $\mathrm{C}$. Augias includes a prologue and a pointer.

The focus is not only on events, people remain significant. The traveler-narrator constantly turns to the images of legendary figures of culture, art, politics, economics. The attentive and observant eye of the publicist notices the smallest details and the most interesting facts from the life of members of the family of monarchs.

The text is permeated with various reflections of the author about the capital of the kingdom, which often end with concise and precise conclusions: "What is the shade of the background of this island and its immense capital? It seems to me that this is the place where the pulse of world life is felt; a great place, despite the loss of its former brilliance and wealth, inhabited by people who are not easy to love, but who are capable of a collective attitude, almost always close to admiration, where greatness and meanness, intolerance and tolerance, sadness and humor are mysteriously mixed up" [1, p. 19].

It should be noted that in addition to the reference materials scattered throughout the text of the book, there are cases of its concentrated submission. Historical background information relates to the history of London in the Victorian era, during World War II, in the sixties, and so on.
The route of the traveler-narrator is divided into fragments of different sizes, each of which has a title that captures the location in geographical space. At the same time, he organizes the sequence of stories about the journey and travel descriptions through architecture, determines the principles of dividing the book into sections.

C. Adjias's guidebook "The Secrets of London" consists of a prologue and seventeen chapters. It is not difficult to notice that the principle of division into sections is spatiotemporal and corresponds to the main fragments of the path passing through the city (for example, "Walk on the East Side," "Magnificent Sixties," "Ghost in the Night," "Beautiful Ghosts with Gordon-Square," "Dust of the Empire").

However, at the same time there are deviations from it, because some sections, for example, have the following names: "Elementary, Watson!," "Bourgeois Artist," "Lady with a Lamp."

Characterizing the path in the work as a whole, it should be noted that it runs through the geographical space of London and is articulated on a huge number of fragments, from which the author selected and reflected the most significant. The level of completeness of reproduction varies, from schematics to photographicity in individual areas or at different times (walking through Trafalgar Square, staying in the London Parliament, traveling through the East Side, Falgate Street, Baker Street, Bloomsbury, a tour of Ras Square and Highget Cemetery, a tour of the gardens of Kew). It is based on its factual and documentary imagery, which is a reflection of what is recorded by the observer while driving on the road.

Let consider first the image of the path as a whole, and then one of its fragments, displayed in detail, which will reconstruct the genre principles that guide the author of the guidebook.

The beginning of the journey is recorded in the first chapter of the book "Walk on the East Side:" "Anyone who wants to truly experience London would like to start on the East Side. This is the poorest area of the city, despite some renovation of its part. But the main value of the East Side is not in the notorious local color, which so often becomes a trap for many tourists, but in the semantic richness, representing in a contrasting sequence of new and dilapidated houses and streets, shameless abundance and pathetic devastation" [1, p. 22]. It becomes clear from these first words of the traveler-narrator that the reader is presented not a simple and quite clear retelling of the trip, but it will be the semantic content of each detail, thoughtful turning of the smallest details: "Before heading to the East Side, let's linger for a while in the center and consider a typical example that allows us to better understand my train of thought: Piccadilly Circus" [1, p. 24].

The narrator marked a new fragment of the path at the beginning of Chapter II: "The most prominent monument, moreover, one that immediately catches the eye of a guest of London, is a column dedicated to Nelson in Trafalgar Square, a distant relative of Trajan's Roman column" [1, $p$. 44].

Further, the narrator does not describe the route, only notes the history of the column, gives chronic references, and retells the strengths of Nelson and his shortcomings in military service. 
Let's analyze in more detail the information in the story about the way regarding the relevance of it to the genre of the guidebook.

C. Augias tries to fix his route quite accurately and clearly. It guides the reader from one place to another, clearly identifying fragments of the path. For example, in section I, we select the following path markers: "I propose to start exploring London precisely from the famous East Side" [1, p. 25]; "In the eastern part of the capital of Great Britain for a few more years it will be possible to "leaf through" the pages of the great history of the city, including chapters of crime. In the first place - Commercial Street" [1, p. 26]; "On the outskirts of Commercial Street, on the Shoreditch side, there is a group of buildings called the Peabody Buildings" [1, p. 26]; “Amazing red brick building at number nine on Brun Street - Jewish Soup Kitchen" [1, p. 27]; "Perhaps the most mysterious house in London has survived here. In this house number 19 on Prinslet Street (street branching from Brick Lane) is the Spitalfields Heritage Center" [1, p. 27]; "If you turn from Prinslet Street to Brick Lane, you can see another building - also the embodiment of a whole page in the history of London. This is how it should be read. The sign on the facade reads: London Jamme Masjid. There is the main mosque of the Hospital Fields" [1, p. 29]; "There is one more street and two stories before we (reluctantly) leave this part of London, so humanly, eloquently and generously allowing us to get in touch with the past. Fashion Street is engulfed in desolation - now sad, now deaf" [1, p. 30]; "The oldest synagogue (Sephardic) in England is in the courtyard between Bevis Marks and Houndsditch" [1, p. 31]; "Let's change the direction. Let's leave the East Side and return to the center "[1, p. 31]; "Pub "Ye Olde Cheshire Cheese" is located in the very center of the city, at number forty-five on Fleet Street, the oldest street, where the editorial offices of leading newspapers have long been located" [1, p. 37]; "Another place is the gallery. More precisely, it is the National Portrait Gallery. If the time seemed to stand still in a pub on Fleet Street, then here it flies" [1, p. 39]; "The next place is house at number forty-eight on Dufty Street, where Dickens lived from 1837 to 1839" [1, p. 41]; "And here's another, last place worth taking a look at. This is so-called the Black Monks Bridge or Blackfriars Bridge" [1, p. 42].

Overcoming the route is accompanied by figurative content - important evidence of authenticity, which allow the reader to walk the path with the narrator.

Thus, the path is displayed concisely due to its articulation by indicating the start and end point of the first thematic route. However, the journey itself does not end.

The composition of the guidebook "The Secrets of London" is completed by landscape islands. They are on the way of the traveler-narrator markers of movement, although isolated on some sections of the road. For example, such a landscape island is found in section IX. The author introduces the reader to the next stop on the route - Russell Square. It is the center of Bloomsbury, famous for its squares and gardens. In order for the reader to fully imagine all the feelings that overwhelmed the traveler-narrator, the text provides a landscape sketch: "On a foggy evening, when the sycamore leaves, darkened with the onset of autumn, barely sway, when the pale facades of houses wash over the remnants of daylight, when, one by one, the windows are lit up, here, like nowhere else, comes the feeling of sublime solitude. Haste and confusion, eternal chaos of traffic, street violence and cruelty, more and more exciting the world, remain outside this place" [1, p. 224]. Then the traveler finds himself in another beautiful area - Gordon Square, more secluded and quiet than others. The landscape description of this place is different from the previous one, but no less emotionally rich, and is built on the opposition "friend" or "foe": "An elegant garden, one of those English gardens that are so different from the wellkept Italian and French parks, where nature is tamed, turned into something artificial, symmetrically combining its colors at the will of man. An English garden is a piece of land barely touched by a man's hand, overgrown with grass and trees, with excellent paths, where the rhythms of the sidewalk edge are filled with, I would say, military severity" [1, p. 228].

Thus, the guide traces the change of the road itself: asphalt, uneven dirt, off-road, paved path, covered with pebbles, on which the traveler-narrator fixed individual road markers. Certain sections of the road were marked by buildings, others by architectural monuments, and some by parks.

It is also important that in order to pass a certain section of the road from the starting point to the final one, a local route must be laid, which will provide movement to a given geographical point and will allow reaching the intermediate goal of the trip. The cognitive effect of the journey is impossible without contemplating the natural phenomena or monuments of civilization that are of interest to the traveler-narrator.

Thus, tracing the path of travelers through the prism of a narrative model of a travelogue with its syncretism of the traveler and the narrator's point of view, we can make some preliminary generalizations. First, the structure of the guide as the basis of a travelogue is clearly traced in the book by C. Augias "The Secrets of London." It reflects the progressive movement of the traveler through the geographical space with the fixation of stops to get acquainted with the area and cultural monuments, just for recreation, or in order to understand the psychology of the national character, to understand the era. In this case, some sections of the road indicate the distance between these markers in kilometers or hours of travel, mode of transport, road features. Secondly, the sequence of movement from one point to the next as a manifestation of the unity of the path that the traveler overcomes, and the angle of the narrator - the genre constant of the guidebook, is followed by the book except for a few fragments. It is worth noting that a significant violation of the sequence is observed in the stories of a trip to the house of Sherlock Holmes (that the fictional literary hero has a real house - a purely English find), a walk through favorite places of "The Beatles," a trip to the "museum"- home, where there is a huge number of works of art collected by Sir John Soan. This is due to the intrusion of mass literary origin, historical past, cultural heritage of the nation, etc. into the genre structure of the travelogue.

Conclusion. Thus, the genre constant of the guide is the subordination of the composition of the work of the route. The role of the author-traveler, participant in events, observer, bearer of a certain worldview is particularly active 
in such books. Documentary elements are also required. The route is to some extent a cast from reality, the parameters of which are set by the author's will. The text of the guide always emphasizes the role of fact, document: the author tries to convince the reader of the veracity of what is described. This sequence of stories about the movement of the traveler through geographical space should be considered as one of the main manifestations of the functioning of the archaic genre model of travelogue [11]. As we can see, the path of the traveler in the book "The Secrets of London" is depicted both schematically - reminiscent of a route, and descriptively (with details, historical references, landscape digressions, biographies) in the style of a guide. The last section is not only the formal completion of the guidebook, the main thing in it is the fact of the end of the journey.
1. Augias, C. (2012). "The Secrets of London." (O. Uvarova, N Chamina, Trans.). M.: RIPOL classik, 528 p. (Secrets of the big city).

2. Alexandrov, O. V. (2015). Travelogue: "Memory of the genre"" Article one: At the intersection of types of mass communication. Dialogue: Media Studios: Zbirnyk naukovykh prats. Odessa. No. 20. P. 7-35.

3. Bidun, A. (2013). Guide as a genre of reference literature in the domestic book market. Kolo. Knyhoznavchyi zhornal. No 5.

4. Vaskiv, M. (2014). Travelogue as a way of knowing the someone else and yourself. Ukrainska humanistyka i slowinskie paralele. Vol. 1. Gdansk; Kyiv, P. 137-157. (Ser. «Problemy współczesnej humanistyki». Retrieved from.: URL: http://elibrary.kubg.edu.ua/5693/7/M_Vaskiv_UHPISP_1_GI.pdf.

5. Huminskiy, V. N. (1987). Travel. Literary encyclopedic dictionary. V. M. Kozhevnikov, P. A. Nikolaev (Eds.).. M., P. 314-315. Retrieved from: URL: https://drive.google.com /file/d/0B 7FIOZ8jMzAqTzljTURWOUtreWM/view.

6. Husieva, O. O. (2014). Modern travelogue: features of the transformation of the old genre. Visnyk Lvivskoho universytetu. Series: Journalism. No. 39 (1). P. 221-226.

7. Zdorovega, V. Y. (2004). Theory and methods of journalistic creativity. L., $268 \mathrm{p}$.

8. Ivanova, O. (2009). Garden of Literature in the journalistic optics of modernity: Mediia komunikatsii z, dlia i pro literatury. Odessa, $368 \mathrm{p}$.

9. Kovaleva, T. V. (2014). Development of the genre of travel essay in the Ukrainian magazine periodicals of the 20-30 of the $X X$ century. Extended abstract of candidate's thesis.. Dnipropetrovsk, 2014. $216 \mathrm{p}$.

10. Maslova, N. M. (1977). Travel notes as a publicistic form. M., $115 \mathrm{p}$.

11. Guidebook [Electronic resource]: Material z Vikipediï - vilnoï entsyklopedii. Retrieved at: ttps: //ru.wikipedia.org/wiki.

12. Rizun, V. (2013). On the question of socio-communicative scientific problems and scientific problems in general. Aktualni doslidzhennia ukrainskykh naukovykh shkil u galuzi sotsialnykh komunikatsii: materialy Vseukrainskoi naukovopraktychnoi konferetsii (Kyiv, April 11, 2013). Kyiv, P. 8-25. Retrieved from: URL: http://journlib.univ.kiev.ua/Articles/Zbirnyk_tez_2013.pdf.

13. Chornous, C. (2009). The evolution of the travel genre in Polish literature. Volyn-Zhytomyr region. Istoriko-fllologichnii zbirnyk z regionalnykh problem. No 19. P. 67-74. 